\title{
Measurement of Strain Imaging, Troponin-I and Brain Natriuretic Peptide Levels in Radiotherapy- Induced Cardiac Injury
}

\author{
Kemal EKICI ${ }^{1}$, Beytullah CAKAL ${ }^{2}$, Onur BAYDAR ${ }^{3}$, Alpaslan MAYADAGLI ${ }^{4}$, \\ Sinem D. CAKAL ${ }^{2}$, Oguz KARACA ${ }^{2}$, M. Onur OMAYGENC ${ }^{2}$ \\ ${ }^{1}$ Inonu University Faculty of Medicine, Department of Radiation Oncology, Malatya \\ ${ }^{2}$ Medipol University Faculty of Medicine, Department of Cardiology, Istanbul \\ ${ }^{3}$ Avicenna Hospital, Department of Cardiology, Istanbul \\ ${ }^{4}$ Bezmi-Alem University, Department of Radiation Oncology, Istanbul,TURKEY
}

\begin{abstract}
Radiotherapy (RT) of the thorax can damage the pericardium, myocardium, heart valves, and coronary vessels, with the pericardium being the most frequently damaged. The objectives of this study were to evaluate RT-induced left ventricular dysfunction and myocardial injury by measuring cardiac biomarkers, troponin I (Tnl) and brain natriuretic peptide (BNP), as well as determin cardiotoxicity and early signs of cardiovascular dysfunction using strain rate imaging (SRI) prior to and following RT. This study included 35 patients diagnosed with thoracic malignancy between January 2011 and October 2013. Of the 35 patients, 22 had left-sided lung cancer and13 had left-sided breast cancer. SRI was performed and Tnl and BNP levels were measured prior to and following RT. A total radiation dose of 40-60 Gy (mean, 54.9 \pm 8.9 Gy) was applied in lung cancer patients and 50-60 Gy (mean, 51.6 \pm 4.9 Gy) was applied in breast cancer patients. No significant difference was observed in Tnl or BNP levels prior to and one month following RT. The left ventricular ejection fraction (LVEF) did not differ prior to or after the first month of RT. However, lower right ventricular strain (RVS) and left ventricular strain (LVS) SRI values were detected within the first month following RT. From the results of this study, we conclude that SRI is a sensitive method to detect RT-induced changes in cardiac function that are not typically detected by conventional echocardiographic methods and cardiac biomarkers.
\end{abstract}

Keywords: Radiotherapy, Cardiac toxicity, Strain rate imaging, Left-sided lung cancer, Left ventricular ejection fraction

\section{ÖZET}

Radyoterapiye Bağlı Kardiyak Hasarlanmada Strain Görüntüleme, Troponin-I ve Beyin Natriüretik Peptid Seviyelerinin Ölçümü

Radyoterapi (RT) göğüs bölgesine uygulandığında en çok perikard olmak üzere myokard, kalp damarları ve koroner damarlara zarar verir. Bu çalışmanın amacı RT uygulanmış hastalarda sol ventrikül disfonksiyonunu ve myokard hasarını kardiyak biyobelirteçler, Troponin I (Tnl) ve Beyin Natriüretik Peptip (BNP) seviyelerini ölçmek ve erken kardiyovasküler erken belirtileri strain rate görüntüleme (SRG) ile RT öncesi ve sonrası belirlemektir. Bu çalışmaya Ocak 2011 ile Ekim 2013 yılları arasında 35 toraks bölgesi kanseri alındı. Otuz beş hastanın 22'si sol meme kanseri ve 13'ü sol taraf akciğer kanseri idi. SR görüntüleme ve Tnl, BNP seviyelerine tedavi öncesi ve sonrası bakıldı. Akciğer kanseri hastalarına 40-60 Gy arası (ortalama, 54.9 \pm 8.9 Gy) doz ve meme kanseri hastalarına 50-60 Gy (ortalama, $51.6 \pm 4.9$ Gy) doz uygulandı. BNP ve Tnl seviyelerinde tedavi öncesi ve sonrası istatistiki olarak bir anlamllık görülmedi. Sol ventrikül ejeksiyon fraksiyonu (SVEF) tedavi öncesi ve tedavi sonrası bir aylık dönemde değişmedi. Fakat, sağ ventrikül gerilimi (SVG) ve sol ventrikül gerilimi (SVG) SRG değerleri tedavi sonrası bir aylık dönemde daha düşük bulundu. Bu çalışmanın sonuçlarına göre, RT hasarının kardiyak fonksiyon üzerindeki erken sonuçlarını tespit etmek konvansiyonel ekokardiyografiye göre SR görüntüleme ile daha duyarlı bir metoddur.

Anahtar Kelimeler: Radyoterapi, Kardiyak fonksiyon, Strain rate görüntüleme, Sol taraf akciğer kanseri, Sol ventrikül ejeksiyon fraksiyonu 


\section{INTRODUCTION}

Radiotherapy (RT) of the thorax damages the pericardium, myocardium, heart valves, and coronary vessels, with the pericardium being the most frequently damaged. ${ }^{1}$ Myocardial ischemia and coronary artery disease are prevalent among young patients undergoing mediastinal irradiation. ${ }^{2}$ It has been reported that thoracic radiation can cause cardiac disease in approximately $10-30 \%$ of patients as early as five years post-radiation. ${ }^{3}$ In patients treated with mediastinal RT, the relative risk of death from a fatal myocardial infarction is increased from 1.5 to 3.0 times that of unirradiated patients. ${ }^{4,5}$ Cardiac tolerance is typically assessed by radiation dose and volume of heart tissue irradiated. ${ }^{6}$ However, additional factors are likely involved in cardiac tolerance. For example, Japanese atomic bomb survivors tend to have a very high risk of cardiovascular disease, even when exposed to low radiaton doses. ${ }^{7}$

The left ventricular ejection fraction (LVEF) assesses cardiac function, but is unable to directly identify cardiac damage. The inability of LVEF to identify cardiac damage occurs from the compensatory reserve of the myocardium, which promotes normal ventricular function even in the absence of functional myocytes. ${ }^{8}$ Developments in echocardiographic imaging, such as strain rate imaging (SRI), have increased the accuracy of myocardial function assessment. Several studies have demonstrated the use of SRI in detecting myocardial dysfunction prior to the occurrence of any changes in conventional echocardiography parameters. ${ }^{9-13}$

Troponin-I (TnI) is widely recognized as a diagnostic marker of cardiotoxicity from cytotoxic chemotherapy treatment. However, use of Tn-I as a diagnostic tool has produced variable and sometimes contradictory results. ${ }^{14,15}$ Brain natriuretic peptide (BNP) is another important biomarker that indicates dyspnea, left ventricular dysfunction, and acute congestive heart failure. ${ }^{16}$ Both TnI and BNP levels may be high and preceed any myocardial damage that could be observed from echocardiography. In this study, we utilized both cardiac biomarkers (TnI and BNP), as well as SRI to investigate RT-induced cardiac toxicity. Thus, the importance of this study is profound, considering few studies have focused on the mechanism by which thoracic radiation alters cardiac blood biomarker levels. ${ }^{17-20}$

Collectively, these results suggest that RT-induced left ventricular dysfunction and myocardial injury can be evaluated by measuring both TnI and BNP levels as well as SRI before and after RT. Furthermore, measurements of both biomarkers and SRI can be utilized to monitor cardiotoxicity and early signs of cardiovascular dysfunction. Therefore, the goal of this study was to investigate the ability of biomarkers and imaging to detect RT-induced cardiac tissue dysfunction and cytotoxicity prior to and after RT treatment.

\section{PATIENTS AND METHODS}

This study included 35 patients diagnosed with thoracic malignancy treated with RT between January 2011 and October 2013. Patients with a history of ischemic or valvular heart disease, abnormal renal tests (creatinine $>1.5 \mathrm{mg} / \mathrm{dL}$ ), and LVEF below $45 \%$ were excluded from the study. Of the 35 patients, 22 had left-sided lung cancer and 13 had left-sided breast cancer.

Radiation therapy was performed using a linear accelerator (LINAC) device and three-dimensional conformal radiotherapy (3D-CRT). In all treatment protocols, 6 or 15 megavoltage (MV) photons were used. For breast cancer boost therapies, electron energy was utilized.

According to the characteristics and localization site of a particular tumor, three-dimensional (3-D) images were created that included the following informations: tumor volume, clinical target volume, planned target volume, and volumes of the organs at risk. Following reconstruction of these tumors, we then planned 3-D conformal RT. 3-D conformal RT planning included determining the fraction dose, which was identified based on the stage and localization of the tumor, as well as the total dose (Figure 1, 2).

Breast cancer patients were treated with adjuvant chemotherapy, and lung cancer patients were prescribed concomitant weekly chemotherapy. Chemotherapy regimens for breast cancer patients consisted of four cycles of AC (doxurubicine, cyclophosphamide), four cycles of AC plus four cycles of docetaxel, or six cycles of FEC (5-fluo- 

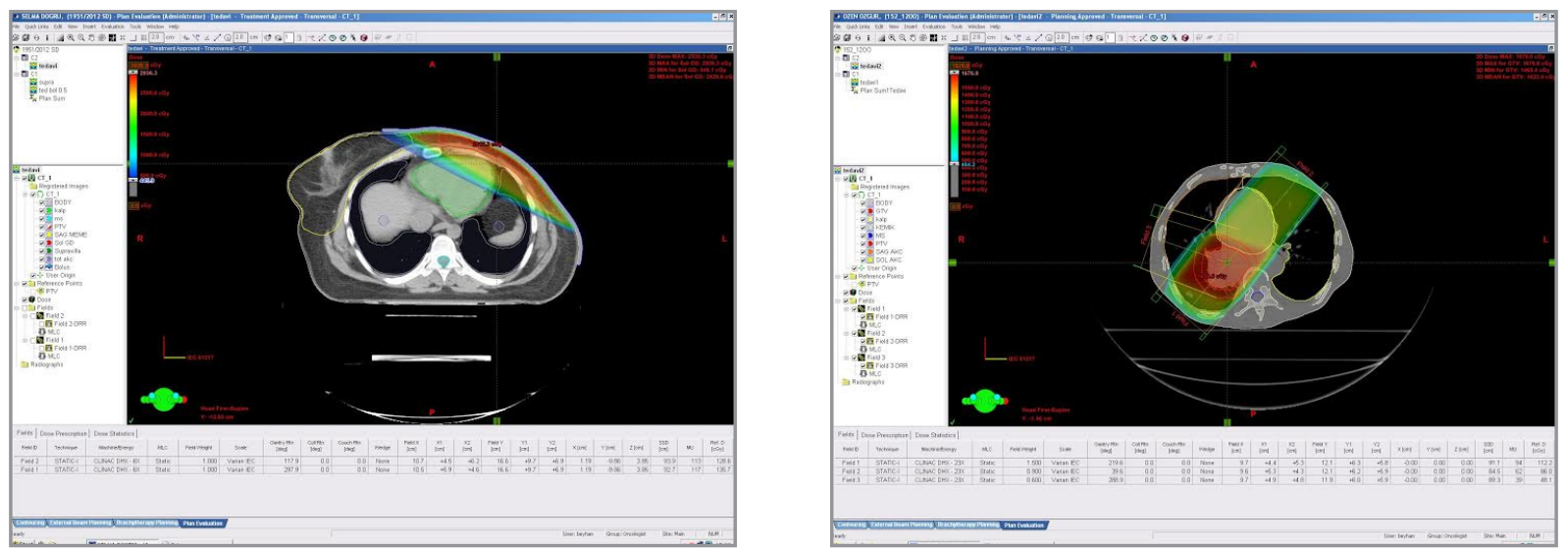

Figure 1 and 2. Treatment plans for postoperative irradiation of the left breast in breast cancer patients and curative irradiation of the left lung in lung cancer patients. Three-dimensional conformal radiation therapy (3DCRT) on breast and lung cancer patients.

rouracil, epirubicin, cyclophosphamide), once every three weeks. Chemotherapy for lung cancer patients consisted of a low dose of cisplatine and docetaxel every week during radiotherapy. Breast cancer patients who had cardiac dysfunction after adjuvant chemotherapy were exluded from this study.

After informed consent was obtained from all patients, blood samples were taken at various times throughout the study to determine levels of biomarkers (i.e. prior to RT, on the last day of RT, and one month after RT).

To analyze the levels of TnI and BNP in serum, conventional enzyme immunoassays were used (Architect stat Troponin-I and Ax Sym BNP, Abbott). The limit of detection for TnI was any concentration less than $0.01 \mathrm{ng} / \mathrm{ml}$; for BNP, $100 \mathrm{pg}$ / $\mathrm{ml}$.

\section{Transthoracic Echocardiography}

Standard gray scale, Doppler, and two-dimensional (2-D) strain (s) and strain rate (SR) imaging were performed using a Vivid 7 ultrasound equipped with a $3 \mathrm{MHz}$ transducer and TDI technology. All echocardiographic studies were performed on subjects in the left lateral decubitus position. Images were digitally stored for offline analysis using EchoPac BT08 software (GE Vingmed Ultrasound).

\section{Standard Gray Scale and Doppler Echocardiography}

For each patient, at least two consecutive heartbeats were analyzed and are represented herein as the mean. Left ventricular (LV) end-diastolic (LVEDD) and end-systolic (LVESD) diameters were calculated from $\mathrm{M}$ mode recordings. $\mathrm{M}$ mode recordings were obtained using a cursor placed at the tip of the mitral leaflets in the parasternal longaxis view, as previously described..$^{13}$ LVEF was assessed using a biplane Simpson method placed in apical four- and two-chamber views. ${ }^{21}$

2D Speckle Tracking Imaging and Postprocessing

2-D S and SRI data were obtained and stored in a cine loop format for offline analysis. In the standard apical four-chamber view, the endocardium of the RV and LV were manually placed in end-systole, and tendocardial borders were then automatically tracked throughout the whole cardiac cycle. We focused our imaging equipment on the cardiac tissues of interest using visual assessment during cine loop playback to ensure that segments were tracked appropriately. Once approved by the reading operator, the software displayed the longitudinal S and SR for the respective segments of RV and LV.

\section{Statistics}

Statistical analysis was performed using the SPSS 15.0 package program. Distribution of the data was 


\begin{tabular}{|lll|}
\hline Table 1. Patient demographics $(\mathrm{n}=35)$ & \\
\hline Characteristics & N & Range or $\%$ \\
\hline Age & 58 (Median) & $36-77$ \\
Male & 20 & $57 \%$ \\
Female & 15 & $43 \%$ \\
Cardiac risk factor & & \\
& Hypertension & 3 \\
Smoker & 23 & $66 \%$ \\
Hypercholesterolemia & 8 & $23 \%$ \\
Diabetes mellitus & 1 & $3 \%$ \\
Diagnosis & & \\
Lung Cancer & 22 & $63 \%$ \\
Breast Cancer & 13 & $37 \%$ \\
Stage of Cancer & & $17 \%$ \\
I & 4 & $35 \%$ \\
II & 6 & \\
III & 13 & \\
IV & 12 & \\
\hline
\end{tabular}

assessed using a Shapiro-Wilk test. A paired Student's t-test was used to determine significant differences between a patient's cardiac injuries from the initial to later visits following RT. Correlations between TnI levels and other cardiac measurements were evaluated using a Spearman correlation test. A P value less than or equal to 0.05 indicated statistical significance.

\section{RESULTS}

The total radiation dose utilized in this study was 40-60 Gy (mean, 54.9 \pm 8.9 ) in lung cancer patients and 50-60 Gy (mean, 51.6 \pm 4.9 ) in breast cancer patients. The dose per fraction in each patient was 1.8-2.0 Gy. Patient diagnoses and treatment details are presented in Table 1. There was no significant difference in the levels of TnI or BNP in patients prior to or within the first month following RT (Table 2).

LVEF did not differ significantly in patients within the first month following RT. However, reduced S and SR values for RV and LV were detected within the first month following RT (Figure 3). The difference observed between $\mathrm{S}$ and SR values for RV and LV in patients did not differ significantly between the last day of RT and one month after RT (Table 3)

\section{DISCUSSION}

Breast cancer is the most common type of malignancy in females. Advances in systemic therapies and RT have provided breast cancer patients the opportunity for extended survival rates. Lung cancer is the leading cause of cancer-related mortality worldwide. RT plays a major role in the management of both breast and lung cancers. Typically, RT is given as an adjuvant treatment for patients with breast cancer and as a curative treatment for patients with lung cancer. ${ }^{22}$

Several epidemiological studies have shown that RT regimens utilized for cancer treatment can increase cardiovascular mortality many years following treatment, especially left-sided irradiation. ${ }^{23-25}$ In this study, we determined that the risk

\begin{tabular}{|c|c|c|c|c|c|c|}
\hline Biomarker & Before RT & Last day of RT & One month after RT & P1 & P2 & P3 \\
\hline Tnl (ng/ml) & $0.020 \pm 0.025$ & $0.030 \pm 0.047$ & $0.020 \pm 0.021$ & NS & NS & NS \\
\hline BNP (pg/ml) & $61.8 \pm 72.6$ & $69.6 \pm 109.2$ & $68.8 \pm 96.4$ & NS & NS & NS \\
\hline
\end{tabular}




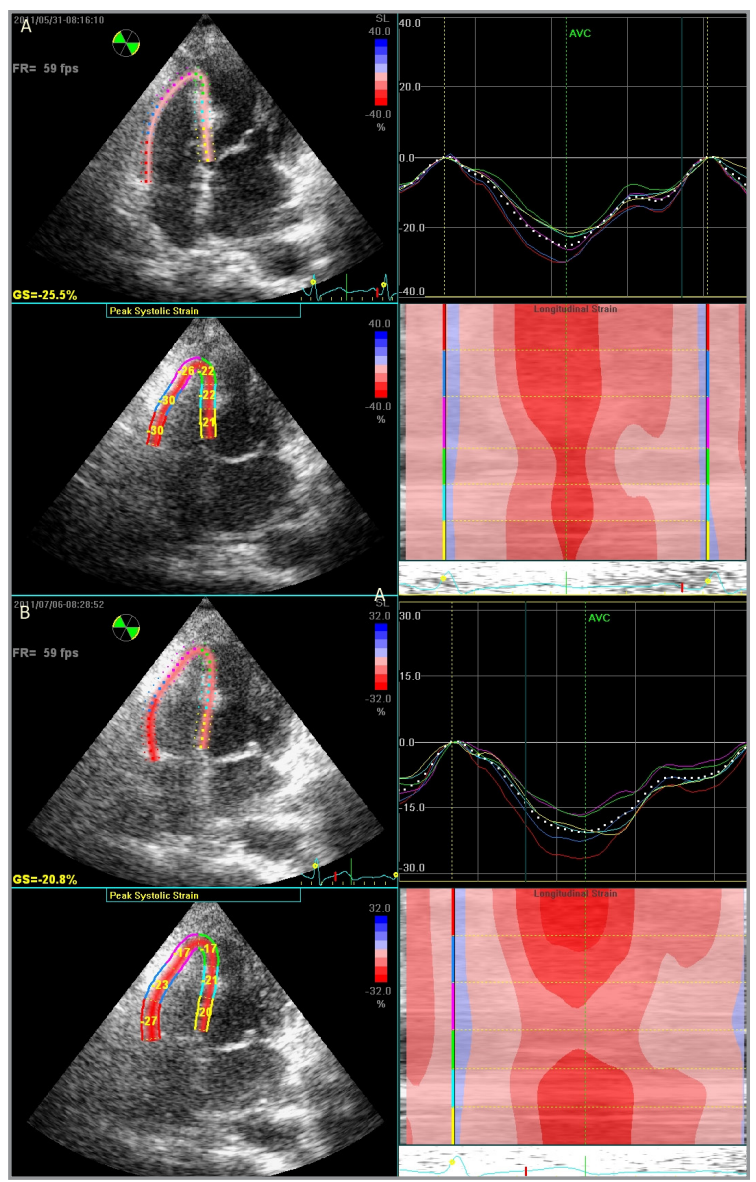

Figure 3. Example of longitudinal strain measures of the right ventricle using the standard apical four-chamber view in a patient with left sided-breast cancer. White dotted line represents the average of six traces for each illustration. Upper left quadrant shows tracking and average peak strain for the segments measured. We concluded that the right ventricular strain decreased early after radiotherapy. of cardiac mortality was $44 \%$ higher in left-sided breast cancer patients than in patients with rightsided breast cancer. ${ }^{8-10}$

The dose of left-tangential radiotherapy has decreased over the past 40 years. Currently, the average dose used to irradiate the heart is $2.3 \mathrm{~Gy}$. However, it is possible for the heart to recieve a higher dose (closer to $20 \mathrm{~Gy}$ ). ${ }^{11}$

The media layer of the heart is the most damaged region when treating patients with RT. During radiation-induced coronary artery disease (CAD), the adventitia becomes markedly thickened and fibrotic compared to the adventitia of individuals diagnosed with non-radiation CAD. In cases of radiation-induced $\mathrm{CAD}$, patients have reduced smooth muscle cells in the media and intimal proliferation of fibrous tissue, which leads to luminal narrowing..$^{25}$ Therefore, it is highly important that RT-induced cardiac damage be detected early.

Cardiac biomarkers, particularly troponins, are widely recognized diagnostic markers for chemotherapy cardiotoxicity. Elevations of serum cardiac troponin levels in asymptomatic patients following administration of anthracyclines can predict myocardial dysfunction. ${ }^{8}$ However, few studies have focused on the role of troponins in the early detection of RT-induced cardiotoxicity. Hughes-Davies et al. quantified serum troponin $\mathrm{T}$ levels in 50 leftsided breast cancer patients before and after RT. However, they did not observe any change in the

Table 3. Standard echocardiographic and strain imaging values before, on the last day, and one month after RT

\begin{tabular}{|c|c|c|c|c|c|c|}
\hline & Before RT & Last day of RT & One month after RT & P1 & P2 & P3 \\
\hline LVEF, \% & $58.5 \pm 1.8$ & $58.5 \pm 1.9$ & $58.6 \pm 1.86$ & NS & NS & NS \\
\hline LVEDD, mm & $43.5 \pm 2.5$ & $43.2 \pm 3$ & $42.8 \pm 3.2$ & NS & NS & NS \\
\hline LVESD, mm & $27.0 \pm 3.3$ & $26.9 \pm 3$ & $27.1 \pm 3.7$ & NS & NS & NS \\
\hline LVS, \% & $-20.3 \pm 4$ & $-19.4 \pm 3.3$ & $-19.2 \pm 3.1$ & 0.036 & 0.033 & NS \\
\hline LVSR, s-1 & $-1.9 \pm 0.1$ & $-1.7 \pm 0.2$ & $-1.7 \pm 0.1$ & $<0.001$ & $<0.001$ & NS \\
\hline RVS, \% & $-22.8 \pm 3.6$ & $-19.8 \pm 3.6$ & $-18.6 \pm 3.8$ & $<0.001$ & $<0.001$ & NS \\
\hline RVSR, s-1 & $-1.5 \pm 0.3$ & $-1.3 \pm 0.2$ & $-1.18 \pm 0.4$ & $<0.001$ & $<0.001$ & NS \\
\hline
\end{tabular}


level of serum troponin $\mathrm{T}$ following $\mathrm{RT}{ }^{26}$ Skyttä $\mathrm{T}$, et al. reported that the increase in hscTnT level during adjuvant RT was positively associated with the cardiac radiation doses for the whole heart and $\mathrm{LV}$ in chemotherapy-naive breast cancer patients. ${ }^{27}$ According to our results, $\mathrm{TnI}$ is not beneficial for measuring RT-induced cardiotoxicity following RT.

BNP is an endogenous peptide produced by ventricular cardiomyocytes as a precursor molecule stored in secretory granules (proBNP). Upon release, proBNP is cleaved by a specific protease into an inactive $\mathrm{N}$-terminal fraction (NT-proBNP) and a BNP active hormone. BNP concentration is a widely accepted biomarker for cardiac failure and cardiac remodeling. Previous studies have suggested BNP's use as a biomarker of radiation damage when radiation was given at high doses. ${ }^{28,29}$ Palumbo I et al. confirmed that BNP could be a useful minimally invasive marker of early RT related cardiac impairment in left sided breast cancer. ${ }^{30}$ However, no increase in BNP levels at any time point was observed following RT in our study.

2-D S was developed to overcome the limitations associated with Doppler-derived strain myocardial deformations. Considering that S and SR imaging are closely related to intrinsic myocardial contractility, these techniques can provide necessary early detection of myocardial dysfunction. ${ }^{31,32}$ The detection of RT-induced cardiotoxicity using SRI has not been well-studied. However, limited but promising data are available with regards to the use of SRI in the detection of anthracycline or trastuzumab-induced cardiotoxicity. Collectively, these studies conclude that measuring only LVEF is not sufficient for the detection of subclinical cardiotoxicity, and instead encourage the use of SRI. ${ }^{8-13}$ Two studies have reported using SRI for the detection of anthracycline-induced cardiotoxicity. These studies investigated the impact of SRI on cardiac tissue treated with a systemic drug. ${ }^{11-12}$ Neither study detected any deformatities in the tissue associated with SRI. In this study, we detected lower SR values for LVS and RVS immediately following RT. We did not observe any changes in LVEF, TnI, or BNP levels following RT. Because the right ventricle recieves a greater amount of radiation exposure due to its anterior location, both S and SRI values for RV declined dramatically early following RT. Therefore, our results indicate that S and SRI are more useful modalities to detect early RT-induced cardiac damage than traditional cardiac biomarkes.

\section{Limitations}

It is important to note the limitations of this study. First, we recognize that a larger sample size may be needed to increase the sensitivity of detection and better understand the influence of other factors on post-RT S/SR reductions. The relevance of $\mathrm{S} /$ SR reductions on myocardial function, as a surrogate parameter for clinical long-term effects of RT, will need further investigation. In our study, breast cancer patients were treated with adjuvant chemotherapy, and lung cancer patients were prescribed concomitant weekly chemotherapy. Therefore, it is difficult to determine if the implications of cardiac side effects were originating from chemotherapy or radiotherapy. There is the potential for RT-induced cardiac disease to occur 10 to 15 years or more following RT. Therefore, further evaluation is needed to determine whether patients with a larger reduction in S/SR values are more predisposed to cardiac dysfunction.

\section{Conclusion}

From the results described in this study, we conclude that SRI is a sensitive method to detect RTinduced changes in cardiac function that cannot be detected by conventional echocardiographic measures and cardiac biomarkers. Subclinical reductions in cardiac function can begin early following RT. Further investigations should focus on whether SRI can be predictive of late cardiac morbidity. SRI has the potential to be an extremely beneficial tool to define patients at risk who could possibly be saved by early initiation of preventive measures.

\section{REFERENCES}

1. Veinot JP, Edwards WD. Pathology of radiation-induced heart disease:a surgical and autopsy study of 27 cases. Hum Pathol 27: 766-773, 1996.

2. Heidenreich PA, Schnittger I, Strauss HW, et al. Screening for coronary artery disease after mediastinal irradiation for Hodgkin's disease. J Clin Oncol 25: 43-49, 2007. 
3. Carver JR, Shapiro CL, Ng A, et al. Vaughn DJ for the ASCO cancer survivorship expert panel. American society of clinical oncology clinical evidence review on the ongoing care of adult cancer survivors: cardiac and pulmonary late effects. J Clin Oncol 25: 3991-4008, 2007

4. Boivin JF, Hutchison GB, Lubin JH, et al. Coronary artery disease mortality in patients treated for Hodgkin's disease. Cancer 69: 1241-1247, 1992.

5. Hancock SL, Tucker MA, Hoppe RT. Factors affecting late mortality from heart disease after treatment of Hodgkin's disease. J Am Med Assoc 270: 1949-1955, 1993.

6. Steele GG. Basic Clinical Radiobiology. London, Arnold Press, 1997: 30-39.

7. Hooning MJ, Botma A, Aleman BMP, et al. Long-term risk of cardiovascular disease in 10-year survivors of breast cancer. J Natl Cancer Inst 99: 365-375, 2007.

8. Altena R, Perik PJ, van Veldhuisen DJ, et al. Cardiovascular toxicity caused by cancer treatment: Strategies for early detection. Lancet Oncol 10: 391-399, 2009.

9. Ganame J, Claus P, Eyskens B, et al. Acute cardiac functional and morphological changes after Anthracycline infusions in children. Am J Cardiol 99: 974-977, 2007.

10. Jurcut R, Wildiers H, Ganame J, et al. Strain rate imaging detects early cardiac effects of pegylated liposomal doxorubicin as adjuvant therapy in elderly patients with breast cancer. $J$ Am Soc Echocardiogr 21: 1283-1289, 2008.

11. Ho E, Brown A, Barrett $P$, et al. Subclinical anthracycline- and trastuzumab-induced cardiotoxicity in the long-term follow-up of asymptomatic breast cancer survivors: A speckle tracking echocardiographic study. Heart 96: 701-707, 2010.

12. Hare JL, Brown JK, Leano R, et al. Use of myocardial deformation imaging to detect preclinical myocardial dysfunction before conventional measures in patients undergoing breast cancer treatment with trastuzumab. Am Heart J 158: 294301, 2009.

13. Erven $\mathrm{K}$, Jurcut $\mathrm{R}$, Weltens $\mathrm{C}$, et al. Acute radiation effects on cardiac function detected by strain rate imaging in breast cancer patients. Int J Radiat Oncol Biol Phys 79: 1444-1451, 2011.

14. Virmani R, Farb A, Carter AJ, et al. Pathology of radiation-induced coronary artery disease in human and pig. Cardiovasc Radiat Med 1:98-101, 1999.

15. Brosius C, Waller BF, Roberts WC. Radiat ion heart disease. Analysis of 16 young (aged 15 to 33 years) necropsy patients who received over 3,500 rads to the heart. Am J Med 70: 519530, 1981

16. Cardinale D, Colombo A, Sandri MT, et al. Prevention of highdose chemotherapy-induced cardiotoxicity in high-risk patients by angiotensin-converting enzyme inhibition. Circulation 114: 2474-2481, 2006.

17. Januzzi JL, Camargo CA, Anwaruddin S, et al. The N-terminal pro-BNP investigation of dyspnea in the emergency department (PRIDE) study. Am J Cardiol 95: 948-954, 2005.
18. Kozak KR, Hong TS, Sluss PM, et al. Cardiac blood biomarkers in patients receiving thoracic (chemo)radiation. Lung Cancer 62: 351-355, 2008.

19. Nellessen $U$, Zingel M, Hecker $\mathrm{H}$, et al. Effects of radiation therapy on myocardial cell integrity and pump function: which role for cardiac biomarkers? Chemotherapy 56: 147-152, 2010.

20. Jingu K, Nemoto K, Kaneta T, et al. Temporal change in brain natriuretic peptide after radiotherapy for thoracic esophageal cancer. Int J Radiat Oncol Biol Phys 69: 1417-1423, 2007.

21. Amundsen BH, Helle-Valle T, Edvardsen T, et al. Noninvasive myocardial strain measurement by speckle tracking echocardiography: validation against sonomicrometry and tagged magnetic resonance imaging. J Am Coll Cardiol 47: 789-793, 2006.

22. Gunderson LL, Tepper JE. Clinical radiation oncology. Thoracic neoplasms and breast cancer. 4th Edition. Elsevier, Part C and F, 2007; 879-1243.

23. Clarke M, Collins R, Darby S, et al. Effects of radiotherapy and of differences in the extent of surgery for early breast cancer on local recurrence and 15-year survival: An overview of the randomised trials. Lancet 366: 2087-2106, 2005.

24. Cuzick J, Stewart H, Rutqvist L, et al. Cause-specific mortality in long-term survivors of breast cancer who participated in trials of radiotherapy. J Clin Oncol 12: 447-453, 1994.

25. Gagliardi G, Constine LS, Moiseenko V, et al. Radiation dosevolume effects in the heart. Int J Radiat Oncol Biol Phys 76: 77-85, 2010.

26. Hughes-Davies L, Sacks D, Rescigno J, et al. Serum cardiac troponin $T$ levels during treatment of early-stage breast cancer. J Clin Oncol 13: 2582-2584, 1995.

27. Skyttä T, Tuohinen S, Boman E, et al. Troponin T-release associates with cardiac radiation doses during adjuvant leftsided breast cancer radiotherapy. Radiat Oncol Jul 10;10:141, 2015.

28. Perik PJ, De Vries EG, Boomsma F, et al. Use of natriuretic peptides for detecting cardiac dysfunction in long-term disease-free breast cancer survivors. Anticancer Res 25:36513657, 2005.

29. Bryant J, Picot J, Baxter L, et al. Use of cardiac markers to assess the toxic effects of anthracyclines given to children with cancer: A systematic review. Eur J Cancer 43: 1959-1966, 2007.

30. Palumbo I, Palumbo B, Fravolini ML, et al. Brain natriuretic peptide as a cardiac marker of transient radiotherapy-related damage in left-sided breast cancer patients: A prospective study. Breast Feb;25:45-50, 2016.

31. Perk G, Tunick PA, Kronzon I. Non-Doppler two-dimensional strain imaging by echocardiography—-from technical considerations to clinical applications. J Am Soc Echocardiography 20: 234-243, 2007. 
International Journal of Hematology and Oncology

32. Rudski LG, Lai WW, Afilalo J, et al. Guidelines for the echocardiographic assessment of the right heart in adults: a report from the American Society of Echocardiography endorsed by the European Association of Echocardiography, a registered branch of the European Society of Cardiology, and the Canadian Society of Echocardiography. J Am Soc Echocardiogr 23: $685-713,2010$.

\section{Correspondence}

Dr. Kemal EKICl

Inönü Üniversitesi Tip Fakültesi

Radyasyon Onkolojisi Anabilim Dali

44280, MALATYA / TURKEY

Tel: (+90-422) 3410660 / 5603

Telefax: (+90-422) 3410728

email: drkemal06@hotmail.com 